\title{
Accumulation of heavy metals in aquatic vegetation of the Barguzin River
}

\author{
Valentina G. Shiretorova*, Svetlava V. Zhigzhitzhapova, Elena P. Dylenova, and Larisa D. \\ Radnaeva \\ Baikal Institute of Nature Management Siberian Branch of Russian Academy of Sciences, 670047, \\ Ulan-Ude, Russia
}

\begin{abstract}
This study is devoted to the analysis of the distribution of heavy metals in the aquatic system of the Barguzin River. This is one of the largest rivers of the Baikal lake system. The element composition of the aerial scion of Potamogeton pectinatus L. (syn. Stukenia pectinata (L.) Borner), Potamogeton perfoliatus L., Hippuris vulgaris L. and Nymphoides peltata (S.G. Gmelin) O. Kuntze of the Barguzin River is studied in this research. One of the main results of the study is the establishment of the following sequence of the accumulation of metals in aquatic plants: $\mathrm{Mn}>\mathrm{Fe}>\mathrm{Cu}(\mathrm{Zn})$ $>\mathrm{Cr}>\mathrm{Ni}>\mathrm{Co}>\mathrm{Pb}>\mathrm{Cd}>\mathrm{Hg}$. Hippuris vulgaris $\mathrm{L}$. contains the highest concentration of the studied metals. Thus, this research provides one of the important steps for the development of regional environmental standards and environmental risk assessments.
\end{abstract}

\section{Introduction}

Due to the technogenic pollution of surface waters with pollutants, the issue of availability and the quality of fresh water is becoming more acute for humanity. Climate change, accompanied by the increase of average water temperatures, melting glaciers, increase in the number of dry periods and floods, only make matters worse [1]. Inorganic pollutants, including heavy metals and metalloids, such as $\mathrm{Cr}, \mathrm{Ni}, \mathrm{Cu}, \mathrm{Zn}, \mathrm{Cd}, \mathrm{Pb}, \mathrm{Hg}$, As, do not decay, unlike organic pollutants. Heavy metals emitted into the ecosystem, due to significant geo-, bioaccumulation and biomagnification, cause a potential risk to human health and the ecosystem [2].

It is well known that aquatic plants intensively absorb macro- and microelements, mineral and organic substances, accumulate heavy metal ions and radionuclides, and are associated with mineralizers and detoxicants, as well as biofilters of pesticides and oil products [3-5]. They are used as objects of indication and monitoring of water quality, eutrophication and pollution of water bodies, and can be industrial raw materials [6-11]. So, various types of hydrophytes of Potamogeton L. and Myriophyllum L. genera has been used to assess xenobiotics' emission into water bodies subjected to anthropogenic stress and to determine

\footnotetext{
* Corresponding author: vshiretorova@ rambler.ru
} 
the possible places of pollutant accumulations in ecosystems [5, 12-14]. Data on the microelement composition of aquatic plants can be used to detect both the initial stages of pollutants emission into water bodies and long-term systematic anthropogenic impacts.

This study was devoted to the analysis of the distribution of metals in the aquatic system of the Barguzin River. This is the third largest rivers of the Baikal lake system. Thus, significant attention to the environmental state of this great lake is a reason for the control of each component of the Baikal catchment area. This study contained the element composition of the aerial scion of 2 species of Potamogeton - Potamogeton pectinatus L. (syn. Stukenia pectinata (L.) Borner), Potamogeton perfoliatus L., Hippuris vulgaris L. and Nymphoides peltata (S.G. Gmelin) O. Kuntze growing in the Barguzin River.

\section{Material and methods}

As a result of the intensive use of water resources of the Barguzin basin (agriculture and forestry), there has become a distinguishable trend in the change of water natural composition and the decrease of their quality, especially pronounced in the lower reaches of the river [15]. The distribution of metals in aquatic plants of the Barguzin River has been studied for the first time. The plants were collected near Barguzin village (N 5336'7,4" E 109³6'20,0"). Plant materials were collected on July 25-27, 2019, without reference to the plant's age. Selected specimens were cleaned from impurities, dried to an air-dry state and grounded. Sample preparation of plant materials was carried out by ashing with concentrated nitric acid in MARS 6 microwave system. The metal content in the samples was determined by atomic absorption spectrometry of an air-acetylene flame on Solaar M6. The mercury content was determined by the cold steam method using a VP-100 hydride attachment to an atomic absorption spectrophotometer. The analysis was conducted in a plant sample with $0.5 \mathrm{~g}$ (weigh) of air-dried biomass, taking into account the plant generic assignment, in triplicate.

\section{Results and discussion}

The results of determination the metal content in the studied aquatic plants are shown in Table 1.

Table 1. The content of metals in aquatic plants of the Barguzin River (mg/kg, air-dry weight)

\begin{tabular}{|c|c|c|c|c|}
\hline \multirow{2}{*}{ Metal } & \multicolumn{4}{|c|}{ Species } \\
\cline { 2 - 5 } & $\begin{array}{c}\text { Potamogeton } \\
\text { perfoliatus } \text { L. }\end{array}$ & $\begin{array}{c}\text { Hippuris } \\
\text { vulgaris L. }\end{array}$ & $\begin{array}{c}\text { Potamogeton } \\
\text { pectinatus } \text { L. }\end{array}$ & $\begin{array}{c}\text { Nymphoides peltata } \\
\text { (S.G. Gmelin) O. Kuntz) }\end{array}$ \\
\hline $\mathrm{Fe}$ & $904 \pm 64$ & $1829 \pm 133$ & $706 \pm 46$ & $111.2 \pm 1.1$ \\
\hline $\mathrm{Mn}$ & $2004 \pm 142$ & $12069 \pm 553$ & $930 \pm 26$ & $199.1 \pm 12.9$ \\
\hline $\mathrm{Zn}$ & $41.7 \pm 2.7$ & $51.3 \pm 2.8$ & $37.8 \pm 0.8$ & $11.4 \pm 2.1$ \\
\hline $\mathrm{Cu}$ & $37.7 \pm 1.7$ & $51.8 \pm 1.5$ & $37.5 \pm 0.5$ & $24.2 \pm 1.8$ \\
\hline $\mathrm{Cr}$ & $7.7 \pm 0.04$ & $12.7 \pm 0,2$ & $11.7 \pm 0.2$ & $4.9 \pm 0.5$ \\
\hline $\mathrm{Ni}$ & $4.22 \pm 0.25$ & $11.7 \pm 0.4$ & $4.7 \pm 0.18$ & $1.5 \pm 0.35$ \\
\hline $\mathrm{Co}$ & $3.92 \pm 0.28$ & $4.82 \pm 0.17$ & b.d.1. & $3.57 \pm 0.43$ \\
\hline $\mathrm{Pb}$ & $1.24 \pm 0.08$ & $3.68 \pm 0.23$ & $0.49 \pm 0.19$ & $1.52 \pm 0.12$ \\
\hline $\mathrm{Cd}$ & $0.43 \pm 0.01$ & $0.70 \pm 0.14$ & $0.49 \pm 0.09$ & $0.63 \pm 0.28$ \\
\hline $\mathrm{Hg}$ & $0.048 \pm 0.002$ & $0.101 \pm 0.002$ & $0.162 \pm 0.003$ & $0.015 \pm 0.004$ \\
\hline
\end{tabular}

b.d.l.- below detection limit

By the level of metal accumulation the studied species can be arranged in the following sequence:

Potamogeton perfoliatus $\mathrm{Mn}>\mathrm{Fe}>\mathrm{Zn} \geq \mathrm{Cu}>\mathrm{Cr}>\mathrm{Ni} \geq \mathrm{Co}>\mathrm{Pb}>\mathrm{Cd}>\mathrm{Hg}$; 
Hippuris vulgaris $\mathrm{Mn}>\mathrm{Fe}>\mathrm{Cu} \geq \mathrm{Zn}>\mathrm{Cr} \geq \mathrm{Ni}>\mathrm{Co}>\mathrm{Pb}>\mathrm{Cd}>\mathrm{Hg}$;

Potamogeton pectinatus $\mathrm{Mn}>\mathrm{Fe}>\mathrm{Zn} \geq \mathrm{Cu}>\mathrm{Cr}>\mathrm{Ni}>\mathrm{Pb} \geq \mathrm{Cd}>\mathrm{Hg}>\mathrm{Co}$;

Nymphoides peltata $\mathrm{Mn}>\mathrm{Fe}>\mathrm{Cu}>\mathrm{Zn}>\mathrm{Cr}>\mathrm{Co}>\mathrm{Ni}>\mathrm{Pb}>\mathrm{Cd}>\mathrm{Hg}$.

The following sequence of metal accumulation in aquatic plants was observed: $\mathrm{Mn}>\mathrm{Fe}$

$>\mathrm{Cu}(\mathrm{Zn})>\mathrm{Cr}>\mathrm{Ni}>\mathrm{Co}>\mathrm{Pb}>\mathrm{Cd}>\mathrm{Hg}$ (exept accumulation in Potamogeton pectinatus and Nymphoides peltata). The highest concentration among the studied metals was determined in Hippuris vulgaris L., the lowest (except As) - in Nymphoides peltata. The manganese content exceeds the iron content in Potamogeton perfoliatus and Hippuris vulgaris, 2 and 6 times, respectively, while in Potamogeton pectinatus and Nymphoides peltata, it is only 1.2-1.7 times. The concentration of zinc and copper in Potamogeton and Hippuris was in comparable amounts, while the copper concentration of Nymphoides had almost twice much of zinc. Iron and manganese were the most intensely involved in the migration cycles in higher aquatic plants, which is associated with their participation in metabolic processes, since these elements are the part of pigments, vitamins, enzymes and, possibly, during the active growing season, they can overcome anticoncentration barriers in excess quantities accumulate by barrier-free type [16]. The highest contents of nickel and cobalt were investigated in Hippuris vulgaris, chromium - also in Hippuris vulgaris and Potamogeton pectinatus. Nickel content was close in both types of Potemogeton, in Nymphoides peltata - the lowest. The cobalt content in Potamogeton perfoliatus and Nymphoides peltata was approximately the same, in Potamogeton pectinatus it was below the detection limit (Table 1). According to the literature a high accumulating ability towards zinc, manganese, and iron was observed in Hippuris vulgaris. However, the authors referred the high accumulation of manganese in Hippuris vulgaris of lakes in Western Siberia to the intense occurrence of photosynthesis, which leads to the oxidation of $\mathrm{Mn}^{2+}$ to $\mathrm{Mn}^{4+}$ on the cell surface due to the increased $\mathrm{pH}$ of the waters of thermokarst lakes [17]. In this case, the more intense course of photosynthesis can be explained by the lower depth growth of Hippuris vulgaris compared to Potamogeton perfoliatus and Potamogeton pectinatus.

Lead, cadmium and mercury are the most toxic and widespread methals. Cadmium ranks first among phytotoxic heavy metals [18]. In living organisms, it can replace zinc in the active centers of metal-containing enzymes, leading to a crude disruption in the functioning of enzymatic processes. In elevated concentrations, cadmium is toxic, especially in combination with other chemical compounds. The mercury content in higher aquatic vegetation can serve as an indicator of water bodies pollution [11]. Since there is no maximum concentration limit of metals in higher aquatic vegetation, it is possible to estimate the pollution of a reservoir by lead, cadmium, and mercury comparing the detected concentrations in other aquatic ecosystems in plants of the same genus.

Lead, cadmium and mercury were found in all studied species of aquatic plants of the Barguzin River. The highest concentration of lead was observed in Hippuris vulgaris (3.68 $\mathrm{mg} / \mathrm{kg}$ ), the lowest - in Potamogeton pectinatus $(0.49 \mathrm{mg} / \mathrm{kg})$. Comparison with literature data showed that such lead content was much lower than indicated in plants of Potamogeton, Hippuris and Nymphoides genera from other reservoirs.

The highest concentration of cadmium was observed in Hippuris vulgaris $(0.70 \mathrm{mg} / \mathrm{kg})$, then Nymphoides $(0.63 \mathrm{mg} / \mathrm{kg})$ and the lowest - in both species of Potamogeton $(0.43-0.49$ $\mathrm{mg} / \mathrm{kg}$ ). The indicated cadmium concentrations in Hippuris and Nymphoides were significantly higher than those indicated in the literature. However, it is necessary to mention that there is only one article where the cadmium content in plants of Hippuris and Nymphoides genera can be find [19]. The concentration of cadmium in plants of Potamogeton genus was higher than that indicated for plants from Siberian water bodies, but significantly lower than from European water bodies [9, 13].

The highest mercury content was found in Potamogeton pectinatus $(0.162 \mathrm{mg} / \mathrm{kg})$, the lowest - in Nymphoides peltata $(0.015 \mathrm{mg} / \mathrm{kg})$. The mentioned concentrations of mercury are 
comparable to the concentration in plants of the Bratsk reservoir with high mercury pollution [11].

\section{Conclusions}

Thus, the results of determination of the element composition of the aerial scion of Potamogeton pectinatus L. (syn. Stukenia pectinata (L.) Borner), Potamogeton perfoliatus L., Hippuris vulgaris L. and Nymphoides peltata (S.G. Gmelin) O. Kuntze, growing in Barguzin River, showed the following order of metal accumulation in aquatic plants: $\mathrm{Mn}>\mathrm{Fe}>\mathrm{Cu}$ $(\mathrm{Zn})>\mathrm{Cr}>\mathrm{Ni}>\mathrm{Co}>\mathrm{Pb}>\mathrm{Cd}>\mathrm{Hg}$. The highest concentration among the studied metals was determined in Hippuris vulgaris $\mathrm{L}$.

Thus, the obtained data of the distribution of heavy metals broadens the understanding of the biochemical characteristics of aquatic plants. This research provides one of the important steps for the development of regional environmental standards and environmental risk assessments.

This research was conducted in the framework of the State assignment of Baikal Instutite of Nature Management, and with partial financial support of The Russian Foundation for Basic Research (Project No 17-29-05085).

\section{References}

1. R.P. Schwarzenbach, Th. Egli, Th.B. Hofstetter, U. von Gunten, B. Wehrli, Annu Rev Env Resour, 35(1), 109-136 (2010).

2. R. Verma, D. Pratima, Recent Res. Sci. Technology, 5, 98-99 (2013).

3. W. Xing, G. Bai, H. Wu, H. Liu, G. Liu, J Soil, 17, 2566-2575 (2017).

4. B.B. Bazarova, Water: Chemistry and ecology, 11, 54-60 (2013).

5. A.P. Kuklin, Water: Chemistry and ecology, 8, 49-54 (2014).

6. I.V. Dovbnya, Freshwater hydrobionts and their biology (Nauka, Leningrad, 1993).

7. N.M. Dayneko, S.F. Timofeev, S.V. Zhad'ko Science and Practice Bulletin, 2, 99-109 (2017).

8. E.N. Philipenko Bulletin of the Transnistrian University, 2, 117-123 (2014).

9. J. Li., H. Yu., Ya. Luan, Int. J. Environ. Res. Public Health, 12, 14958-14973 (2015).

10. D.P. Phillips, L.R.D. Human L., J.B. Adams, Mar. Pollut. Bull., 92, 227-232 (2015).

11. M.G. Azovsky, M.V. Pastukhov, V.I. Grebenshikova, Water: Chemistry and ecology, 8, 20-24 (2010).

12. A.A. Fomina, E.I. Tikhomirova, A.I. Korableva, Modern problems of science and education, 6 (2015)

13. C.A. Harguinteguy, M.N. Cofré, A.F.-Cirelli, M.L. Pignata, Microchem. J., 124, 228 234 (2016).

14. F. Duman, O. Obali, D. Demirezen, Chemosphere, 65, 2145-2151 (2006).

15. V.V. Dryukker, L.M. Sorokovikova, V.N. Sinyukovich, T.G. Potemkina, I.G. Nikulina, O.A. Molozhavaya, I.V. Korovyakova, Geography and Natural Resources, 4, 72-78 (1997).

16. M.Yu. Puchkovm V.P. Zvolinsky, V.V. Novikov, A.I. Kochetkova, E.G. Kochetkova, E.G. Loktionova, Basic research, 6, 392-396 (2013).

17. R.M. Manasypov, O.S. Pokrovsky, L.S. Shirokova, S.N. Kirpotin, N.S. Zinner, The news of Tomsk Polytechnic University, 329, 50-65 (2018).

18. D.M. Dikieva, I.A. Petrova, Hydrobiological processes in water bodies (Nauka, Leningrad, 1983).

19. L. G. Vardanyan, B S. Ingole, Environ. Int., 32, 208-218 (2006). 